\title{
Picturing creative approaches to social work research: Using photography to promote social change
}

Michele Jarldorn Flinders University, Australia

\begin{abstract}
INTRODUCTION: This article argues for the benefits of employing the arts-based method known as photovoice. Drawn from a social work PhD project with 12 South Australian exprisoners, this research aimed to better understand the post-release experiences within the context of a rising prison population and high recidivism rates.

METHODS: Participants were given a single-use camera and the research question if you had 15 minutes with a policy maker or politician, what would you want to tell them about your experience? Later, the participants' narratives were combined with the photographs and used to create an art exhibition with the rationale that images are more likely to resonate with people than words alone.
\end{abstract}

FINDINGS: Using photovoice in this way has the potential to create new knowledge through the process of participants constructing and retelling accounts of their experiences via the medium of photography.

CONCLUSION: I propose that the process of turning research into praxis through participatory action-based methods such as photovoice can be a positive, empowering experience for the participants and researchers.

KEYWORDS: photovoice, ex-prisoner, arts-based social work research, photography, creative approaches

The majority of Australians appear to have moved on from our prison beginnings and, while once shameful, many people now embrace their convict ancestry (Tranter \& Donoghue, 2003; Williams, 2015). Australian convict sites are tourist attractions. Visiting the decommissioned Adelaide Gaol (now a museum) in South Australia is advertised as definitely one of the things to do in Adelaide (Adelaide Gaol Preservation Society, 2015). Visitors to prison museums participate in what is described as Dark Tourism (Brook, 2009; Wilson, 2008), where people pay money to enter locations of past pain and suffering. Reliant on tourist dollars, the "public-history marketplace" (Wilson, 2008, p. 216) of prison museums compromises the stories of suffering of people who have been incarcerated, privileging the narrative of tour guides, the majority of whom are ex-prison officers. Accordingly, ex-prisoners are othered in this process of "promoting penal populism" (Wilson, 2008, pp. 216-217). The somewhat sanitised and binary accounts of us and them found in prison museums, media, and popular culture (Green, 2009; Kohm, 2009) minimise the broader experience of people who have been in prison. As Faith (2000) argues, "only someone who has been imprisoned can speak subjectively of this experience" (p. 158). Further, such one-sided accounts ignore
AOTEAROA NEW ZEALAND SOCIAL WORK 28(4), 5-16.

CORRESPONDENCE TO: Michele Jarldorn michele.jarldorn@flinders. edu.au 
the question of how society uses prisons to disappear social problems (Davis, 2003) and how released prisoners are rarely welcomed upon their re-entry into the community.

Unlike early convict ancestry, connections with today's ex-prisoners are seldom embraced. Instead, such connections are a source of stigma and shame that can dissolve family and community connections, preventing the development of new networks and relationships. Yet strong networks are important, as they are known to contribute to the ability to stay out of prison (Arditti, Lambert-Shute, \& Joest, 2003). Negative stereotypes prevent exprisoners from finding work, housing, and reconnecting with their children. Without overcoming these barriers and attitudes, ex-prisoners remain at risk of returning to prison, for many the one place where they feel accepted and part of a community (Clemmer, 1940; Jarldorn, 2016; Terry, 2003).

Negative representations of who or what constitutes an ex-prisoner dominate the public landscape. Public opinion is generated by the 24-hour news cycle and tough on crime policies which enable politicians to score points by appearing to respond to public opinion (Green, 2009). People in conflict with the law are seldom consulted in the development of policies and procedures that directly affect them. Yet policies, legislation, social service provision, and the associated bureaucratic structures are often damaging rather than beneficial (Halsey, 2007). Perhaps, their input is omitted because society believes that they have lost any right to speak because they have been convicted of a crime. There may be anxiety that the opportunity will be a stage for the public disclosure of personal pain, or that if given a voice it will be used as a platform to protest their innocence. No matter what the reason, being able to contribute to the creation of policy through their own voice is something that is seldom afforded to people who leave prison, despite their intimate knowledge of procedures and organisations involved in the criminal justice system. This project aims to address this omission.

\section{Photovoice and social work}

Photovoice is a participatory action research method, which is influenced by feminist theory, Marxist philosophy, and particularly Freire's (1970) notion of the power of critical pedagogy. Although many researchers have creatively modified photovoice to suit their own community needs (Castleden \& Garvin, 2008; Jarldorn, 2016), essentially a photovoice project has community members come together to decide which issues are most important to them. Members of the community become both participants and researchers, heading out into the relevant community and taking photographs that represent their concerns. Participants and facilitators then meet as a group to analyse the photographs, later taking these findings to a wider public with the intent of influencing policy decisions. The rationale behind using images is that they are likely to resonate with time-poor policy makers by creating lasting reminders that words alone would not (Wang \& Burris, 1997).

Used as a tool for community action, photovoice aims to empower the disempowered, encourage community members to engage in mutual aid and to influence policy through social action (Molloy, 2007). By facilitating ways for community members to portray the realities of their oppression, photovoice is a means for seeking social justice and nurturing "self-advocacy" (Molloy, 2007, p. 45). It has the potential to educate the wider community while simultaneously raising the consciousness of both participants and researchers / facilitators (Castleden \& Garvin, 2008). Sometimes, photovoice has been used more specifically as a form of group work, enabling group members to see that they are not alone in their private pains, and highlighting how the personal can also be political. Photovoice has also been used as a research method, where (usually) academics create or rely on an existing relationship with a group or community with a view to working towards a common goal. 
Despite the apparent ease of fit between photovoice and social work research, relatively few projects from the social work discipline have used photovoice (Catalani \& Minkler, 2010). This may be due to the professionalisation of social work practice (Anleu, 1992), whereby expert insights are preferred over lived experience (Brown \& Strega, 2005). Further, the commitment to grassroots community-driven research to inform policy and practice has been backgrounded by dominant understandings of evidence-based practice (Webb, 2001). Neoliberal approaches to welfare provision encourage social workers to fix individuals, manage risk, and meet key performance and quality assurance indicators (Baines, 2011; Beddoe, 2010; Ferguson, 2004; Ferguson \& Woodward, 2009, p. 110; Wallace \& Pease, 2011). However, as Ife (2009) has argued, employing community development thinking is a useful framework for all modes of social work-including research-in upholding social work's core tenets of participation, human rights and social justice (Ife, 2009). For those of us who have our social work roots firmly planted in community development, photovoice offers an egalitarian bottom-up research method. The following discussion expands on the theories that inform photovoice.

\section{Photovoice theories: Feminism, Marxism and critical pedagogy}

Feminist research methods strive for researcher reflexivity and equitable power relationships, acknowledging that it is those with power that determine discourse. Photovoice enables a sharing of power between participants and researchers, as it is the participants who choose which issues they would like to address. Their input is also integral to analysis of the data produced. Feminist methodologies aim to give equal attention to the "social and cultural context of events as well as the events themselves" (Parr, 1998, p. 89). Reinharz (1992) explains that "feminist research is connected to social change" (p. 251) and is "practical as well as scholarly" (p. 252). These phrases are applicable to both the purpose of photovoice and the project of social work. Fook (1993) reminds us that unlocking the consciousness of the oppressed, as a way to empower individuals and communities is central to feminist theory. Importantly, research that is designed using a feminist framework will challenge normative gender stereotypes and expectations throughout its analysis. Although there are many different feminisms, common amongst them is the understanding that the oppression of women holds everyone, women and men, back from realising their full potential.

Engaging with the work of Marx and Freire can initially be challenging and especially confronting for feminists because of their use of male-centric language. For some, this has given reason to dismiss or ignore their work. Yet many feminists, along with members of other social movements whose goal is to end oppression "identify strongly with a Marxist class analysis" (Dunbar, 1970, p. 486). In reading the scholarship of Paulo Freire, bell hooks (1994) describes his use of sexist language as a constant "source of anguish" for herself and other feminists, but argues that we would be ignoring a valuable resource if we do not learn from Freire's "critical insights" (pp. 49-50).

Freire's theories $(1970,1998)$ have strongly influenced the photovoice methodology (Wang, 1999). For Freire, critical pedagogical approaches can empower individuals and entire communities. Critical pedagogy, or learning within the context of "social, political, and economic contradictions" (1970, p. 35), can simultaneously emancipate people from their oppression and, by educating their oppressors, liberate them from their own power. Henry Giroux explains the power of Freire's critical pedagogy, believing that it offers...

a way of thinking beyond the present, soaring beyond the immediate confines of one's experiences, entering into a critical dialogue with history and imagining a future that did not merely reproduce the present (Giroux, 2010, para. 7). 
Freire's concepts around teaching often resonate with the activities of social workers (Hegar, 2012). He challenges the power implied by the dichotomy of teacher and student, arguing that "there is no teaching without learning" (Freire, 1998, p. 29). Related specifically to photovoice and social work, this translates more closely to the client and the worker, or the researcher and the researched, where interventions and research can perpetuate and re-inscribe power differentials and social injustice. According to Freire's pedagogy, the teacher, social worker, or researcher should be aware that together with the community in question, their shared knowledge, skills, and abilities are more powerful than if they were to work separately.

Photovoice is further informed by Marxist theory (Molloy, 2007). Marxism, according to Cox and Nilsen (2014), focuses on the "structural nature of social problems and political issues" by drawing on the knowledge of people "who do not hold power, own the means of intellectual production, or benefit from high cultural status" (p. 5). When Marx wrote that "philosophers have only interpreted the world, in various ways; the point is to change it" (Marx, 1972, p. 109), he was, like Freire, advocating for "praxis". Both Marx and Freire held that people could not be liberated from oppression by the oppressor, but had to participate in revolution to grasp their own liberation. As Audre Lorde (1984, p. 123) has argued, "the master's tools will never dismantle the master's house," meaning that liberation gifted to the oppressed would always include caveats and clauses that would ensure that the status quo was maintained.

\section{Social work and alienation}

One of the key concepts of Marxism is that of alienation. Marx and Engels have argued that when work becomes the sole focus of people's lives, they become alienated from the natural world, and only able to see themselves within the myopic lens of production (Marx \& Engels, 1972; Ollman, 1971). More than ever a person's worth in, and value to, society is judged by their connection with-or disconnection fromthe workforce (Ferguson, Lavalette, \& Mooney, 2002; Henman \& Marston, 2008; Mendes, 2003). People who transgress mainstream norms or who live on the margins of society, such as former prisoners, experience powerlessness in the form of alienation (Petersilia, 2003). The alienation created by social stigma has been described by Harvey (2010) as civilised oppression, where the use of social power, rather than physical violence or law, effectively excludes and isolates (Harvey, 1999, 2010). Civilised oppression is covert, hard to name, easy to internalise while at the same time difficult to alleviate (Harvey, 2010).

Alienation is experienced by the majority of people who are social service users and such feelings are often shared by social workers, leading them to feel disconnected and disillusioned (Ferguson \& Lavalette, 2004; Lavalette, 2011). The current impersonal and individual nature of customer-focused welfare services does little to bring people together (Ife, 2009). Many social workers feel that they have lost the ability to perform social work that is meaningful to both service users and themselves (Ferguson \& Lavalette, 2004; Ferguson \& Lavalette, 2007). In a society that continues to be driven by neoliberal ideology (Ferguson, 2008; Giroux, 2002), building solidarity and strong relationships between service users and social workers (Beresford, 2011) is becoming more difficult. The social work profession continues to be "distorted and undermined" as we work to fit within business models (Ferguson \& Lavalette, 2007, p. 59) and risk assessment paradigms. As will be described, the use of photovoice as a research method can pave the way for meaningful engagement with research participants and generate public interest in research findings while challenging stereotypes and assumptions. 


\section{Art, photography and action}

Alienation or a "deadening of the senses" of the oppressed within the capitalist world can be countered, in part, by participation in the arts (Reitz, 2000, p. 15). Participating in the creation of art, such as photography, exercises the human ability to be creative and can provide a sense of satisfaction, and fulfilment in presenting the truths of class struggle (Fischer, 1963; Marx, Engels, Baxandall, \& Morawski, 1973). Using a Marxist perspective, Fischer (1963) describes art as a "magic aid towards mastering a real but unexplored world" capable of "illuminating social relationships" and "helping men [sic] to recognise and change social reality" (pp. 13-14). As Davis (1984) explains, the seeds of emancipation and radical social change can be sown when we engage with explicitly socio-political art (p. 216).

Although there have been arguments to the contrary, photography is an art form (Prodger, 2012). Like other art forms, participating in the art of social action photography can protest against injustice, raise awareness of social issues and potentially help to heal individual pain. Without doubt, the use of images and photography can better illustrate the severity of social injustice (Marshall, Craun, \& Theriot, 2009) than words alone. Writing about its potential to challenge the way we see and think about the world, Marvin Heiferman (2012) explains the power of photography:

Photographs don't only show us things, they do things. They engage us optically, neurologically, intellectually, emotionally, viscerally, physically. They demand our scrutiny and interpretation. Photographs seduce and motivate us; they promote ideas, embed values and shape public opinion. (p. 16)

It has been argued that social work itself is an art form (England, 1986; Gray \& Webb, 2008; Stirling, Warren, \& Paton, 2014), an artful practice that employs a combination of art, science, heart and ethics (Steinberg, 2006). It is an art form that can be enriched by the use of images. For example, images and photography can be used as a tool in therapy (Decoster \& Dickerson, 2014), in group work (Craig, 2009), by social activists (Bogre, 2011) and to humanise findings in social work research (Jarldorn, 2016; Russell \& Diaz, 2013). Social workers have long recognised the benefits of participation in the arts as a means of realising social equity (Anwar McHenry, 2011). More than a century ago, Jane Addams introduced arts programmes at Hull House as a means of self and collective expression (Addams, 1912; Brieland, 1990). In the 1920s, Wallace Kirkland, social worker and photographer, taught photography to children at Hull House, while documenting everyday events and activities (Foerstner, 1989). Lewis Hine was employed by social workers as an investigative photographer for the National Child Labour Committee in the United States (Lockett, 2011) to highlight the exploitation of child labour.

Done properly, photovoice is a labour intensive research method that requires time to build relationships with people and their community. This could be considered a drawback, especially as the neoliberal agenda dominating social services and university models expects us to rush through interventions and complete doctoral dissertations quicksmart. However, the time investment is valuable as it is more likely to facilitate trusting alliances, ensuring that the method is true to its promise of challenging the conventional power dynamic of researcher and researched. It is these liberatory relationships (Beresford, 2011) that have the potential to truly inform knowledgebased practice (Glasby \& Beresford, 2006). Although at times the data produced in this project has been difficult to manage because of its variety and breadth, this same depth and reach has been positive in terms of engaging the public. 


\section{Ethical considerations}

The inherently political nature of research with ex-prisoners, particularly the likelihood that a participant would identify as First Nations Australian (given their overrepresentation in custodial settings) and the strict rules around mixing with other ex-prisoners, meant that I had to carefully think through each step of the project. I consulted texts on the protocols of research with First Nations peoples and accessed a number of photography theory texts to build my understanding of issues around the politics of representation (for example, see NSW Art Gallery, 2008; Ruby, Gross, \& Katz, 1988; Sontag, 1977, 2003; Spence \& Solomon, 1995). The original university ethics application was approved with minor revisions and as the project progressed, additional modifications ensured that the project continued to be grounded in ethical research principles.

\section{Procedure}

Full participation in this project required a significant number of meetings and points of contact with the participants. The criteria for participation were that a person had spent time in a South Australian prison and that they did not want to return. Nine women and three men have completed each step of the project. Another eight people, including five First Nations Australians who had indicated that they wanted to participate, dropped out of the project before completing each step. Although disappointing, this dropout rate reflects the reality of postrelease and the rates of prison re-entry. It is likely that a project like this would better represent First Nations Australians if the researcher was a close member of their community, rather than a white, middle-aged woman such as me.

Consent and full participation was a lengthy process. Interested participants were posted an information package containing participant information sheets, consent forms and letters of introduction. They were asked to ensure that they understood what constituted full participation and the purpose of the research. They were encouraged to have a trusted friend or family member look at the material with them and to contact me for further clarification. We then met individually and I described the project in more detail.

I explained why I was doing the research and why I had chosen to use photovoice. Although I sought basic demographic information, I did not press for the details of participants' criminal activity, although most provided this information openly. Each participant chose their own pseudonym, which has been used here and throughout the project. We talked broadly about their experience. Here I used an iterative process, building on what I learned from earlier conversations to discuss emerging themes and ideas with subsequent participants. Participants were shown a journal article that indicated how their data would be used and provided with a small handbook that I designed for the project. Using plain language and simple images, the handbook describes the photovoice method, discusses ethical issues, and provides hints and tips for photo composition.

In the spirit of photovoice, I hoped that the participants understood that their perspectives and experiences would be validated. I wanted the participants to understand themselves as researchers, who were generating their own data. Accordingly, each participant was given this research question: "If you had 15 minutes with a policy maker or politician, what would you want to tell them about your experience?" From this point on, the participants became researchers, left to decide which issues they wished to focus on. Importantly, they were not constrained by my potentially narrow set of research questions.

Although the participants were given a single-use camera to collect their data, 
around half used their mobile phone or a digital camera to produce their images instead. Some participants returned the camera by post; others sent the images via email or SMS. I then loaded their images onto a PowerPoint ${ }^{\mathrm{TM}}$ file on my laptop. We met again to look at the photographs together. We talked about what messages they were attempting to convey with their photographs and linked their personal experiences within a broader social and political context. These discussions were recorded and transcribed verbatim. As well as being provided with a small album of their photographs, the participants were given a word-cloud of their transcribed interview ${ }^{1}$, which was enthusiastically received. From the 12 participants I heard stories and saw photographs that replicated research findings from many large and international projects. However, there have also been some important differences in this research. The personal nature of the project has meant that the participants were comfortable in presenting unique perspectives that I can find no reference to in existing literature regarding ex-prisoner experiences. For example, seven of the nine women who participated in the research submitted photographs and narratives about the importance of companion animals in their lives, before, during, and after their imprisonment (Figure 1).

\section{Art, new knowledge and informing policy}

A criticism of some photovoice projects is an omission to display the work in the public sphere (Kuratani \& Lai, 2011). As the purpose of this project was to facilitate a means for ex-prisoners to tell their own story and to challenge common assumptions made about them, I knew that the material needed to be seen by a wide audience. I also wanted to ensure that participants could engage with the material on their own terms-to be able

1 This was done using the website tagxedo.com.

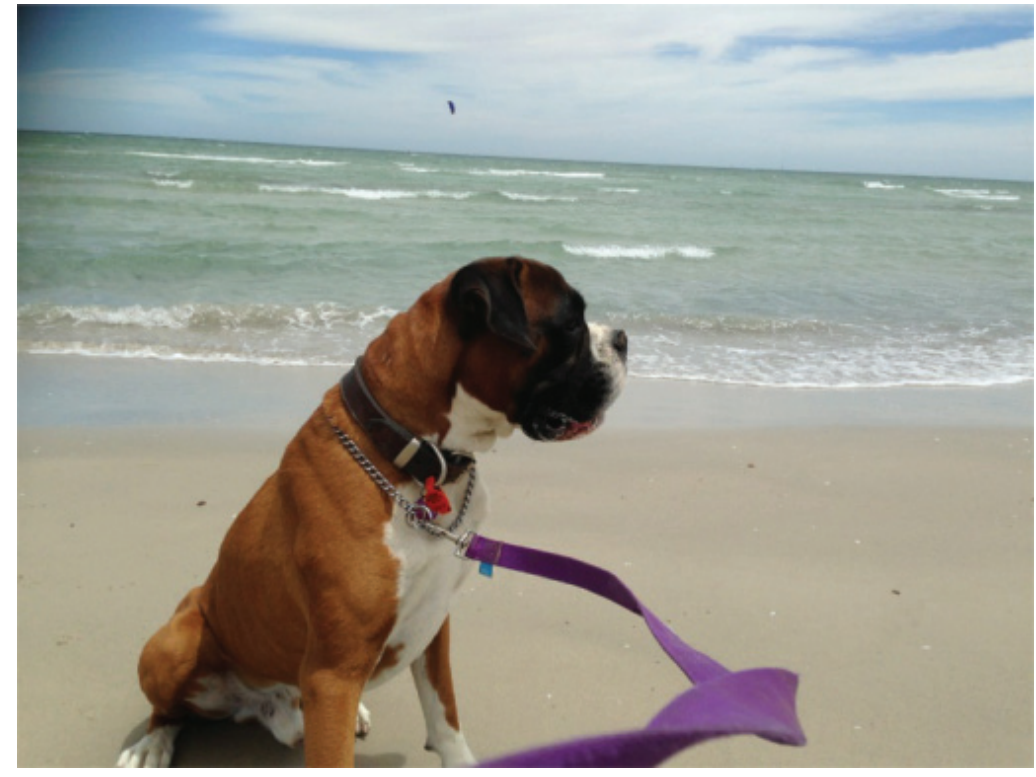

Figure 1: My Dog Costa

I just love my dog to bits, he went through it all with me. Before I went to prison I was in a really depressed state, not knowing what was going to happen. I withdrew from the world and isolated myself. He was just always there for me. I would cry all the time and he would come and put his head in my lap. He could sense how I was feeling. I don't know what I would have done without him. When I went to prison I used to wonder what Costa was thinking, perhaps he thought I was dead. I got to come home for a few hours a month before I was released. He was so excited, but then I had to go again. It must have gotten so confusing for him. I mean, I could see my partner when he came to visit, but not my dog. I missed him terribly (Feeney).

to invite anyone they wished and to take as long as they wanted to view their own and other participants' work. A solution was to present the material as an event at the 2015 Adelaide Fringe Festival. The Fringe is an annual, open access arts festival. Created in 1960 as a covert grass roots alternative to the sometimes stuffy and elitist Adelaide Festival of Arts, the Adelaide Fringe is the second largest fringe festival in the world. Eltham (2009, p. 44) argues that arts festivals were created as a "platform for the flowering of the human spirit". For a small registration fee (AUD220 for a three-day event), anyone with a creative vision can hold an event as long as they have access to a venue. The venue I used was the foyer space in my university's city campus, at no cost to me. 
The next step was to prepare the participants' data for display; to present it as art. I chose around 110 of the images and had them printed at a self-serve photodeveloping kiosk. Using this inexpensive technology allowed me to modify, crop and enhance photographs, within a short turnaround time. I purchased black cardboard folders from a wedding photography supplier. On one side, the 8 " $\times 10^{\prime \prime}$ enlargements could be slipped into the frame, while each participant's narrative, printed on quality parchment paper, was attached on the opposite side. In preparation for the exhibition, I grouped the material into themes on my kitchen bench (see Figure 2). Although I had indicated

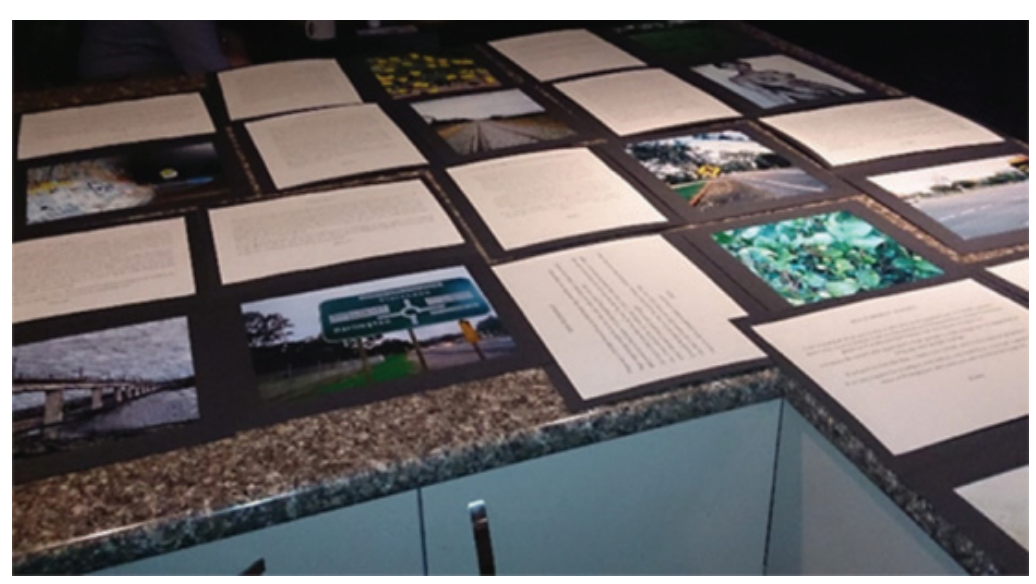

Figure 2: Kitchen bench thematic analysis

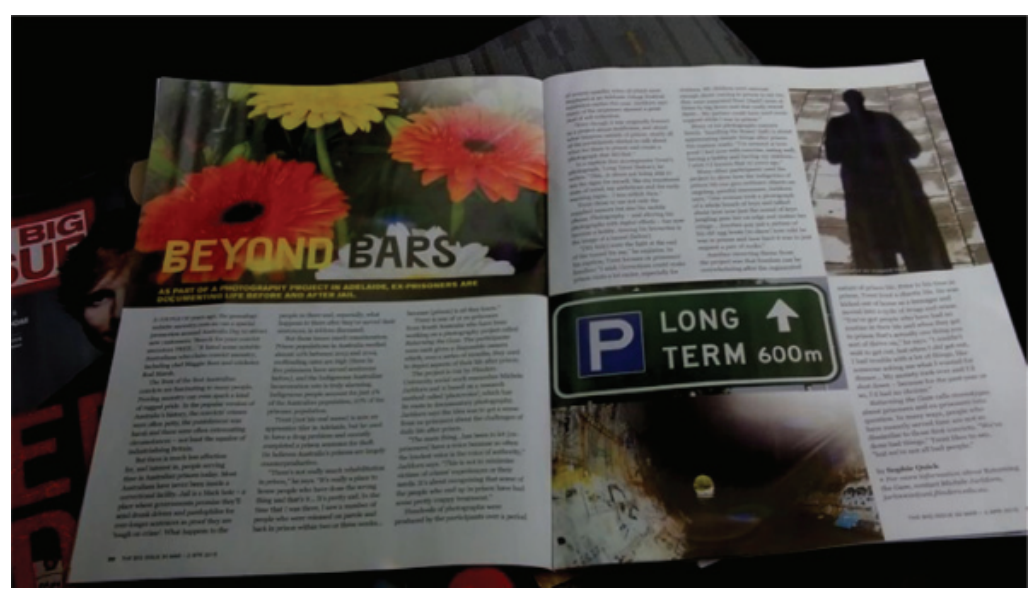

Figure 3: The article in The Big Issue (Quick, 2015) in my research proposal that I would use NVivo software (QSR International) to analyse my data, I realised that the use of a software programme is counter-intuitive to my grassroots approach. At the heart of the photovoice method is the promise of egalitarian sharing of data analysis. Therefore, I decided that using a computer programme unavailable to participants involved an overt use of researcher power and went against the promises I made to participants and myself about the unique approach of the project.

Participants had already performed the first level of analysis during our discussions about their photographs. I took the next step and linked them together in similar themes. The visual element made this a relatively straightforward process. Four themes arose: (a) pre-prison, (b) in-prison, (c) post-release difficulties, and (d) hopes and dreams for the future. The cardboard folders were a good choice as they are light enough to be pinned onto room dividers, they can stand like a greeting card, be passed around a small group, while in between exhibitions they are light and compact enough to be stored in a filing cabinet.

Invitations to display the material and talk about the project have continued long after the original exhibition, proving the potential of images to complement and enhance qualitative research. This is significant because the main purpose of photovoice is to inform policy and, as Wang and Burris (1997) point out, it is public opinion that shapes policy. Specifically for this project, continued exposure of the material and feedback from visitors builds a strong case for the inclusion of ex-prisoner voices and expertise in public policy discourse. This would not have been possible without the use of images as data. For example, my Fringe media release caught the attention of a journalist from the street magazine, The Big Issue, who interviewed me and one of the participants, Trent, using his photographs and story for a feature in their magazine (Figure 3). 


\section{Benefits of exhibiting the material}

Many of the participants were able to attend the Fringe exhibition. Some came alone, but others came with family members, their partner, or friends. Participants introduced me to their guests. It was satisfying to witness them interacting with their own and other participants' work. Having their experience validated in such a prominent location in a prestigious arts festival was helpful for the participants, while for me, being available during the entire three days led to many conversations with visitors to the exhibition. Visitors took time to read the participants' stories and in doing so began to understand the broader social implications of the use of imprisonment and the collateral damage that is experienced by families and communities. Being present to answer the questions raised by people who viewed the work also presented me with perspectives I had not considered. Visitors to the exhibition had the opportunity to provide anonymous feedback. Below are some of the comments, which illustrate the impact of the participants' work in challenging stereotypical assumptions.

The use of photographs alongside the stories gave an insight into a world most of us might know very little about.

The dignity and human rights of prisoners escapes the minds of society. This exhibition brings insight to the need for prisoners to remain in society for rehabilitation and treatment.

Powerful in expressing the progression of thought and the self-awareness of these people.

This was an incredible learning experience. There are many common themes like addiction, social isolation, and no rehabilitation.

In reading, I felt like I got to know each one personally.

Informative and highlights the emergency and need for change.
This is such a powerful affirmation of humanity. It just brings home to me how much we all really have in common, that there is not an "us and them", but a "we". I am grateful that the participants were prepared to share their stories so openly.

A rewarding aspect of this research has been the feedback given by the participants about how they experienced contributing to the project. Kate brought her sister to the exhibition. Kate told me "seeing all these stories together has really helped [my sister] to understand what I went through". By validating their experiences, the participants have felt connected to the project. Via SMS, email and personal communication, most participants reflected on their participation:

Gidget: Thank you Michele. From participating in this project, I have actually learned more about what I'm capable of.

Trent: Hi Michele, I was very happy to see the work you have done with our photographs and stories. The interest you have shown without judgement is so rare to see in a person. So, thank you for getting our messages out there for the public to maybe get a better understanding of ex-prisoners-that we did bad things but we are not all bad people. Thank you for involving me, it has been a pleasure.

Georgia: Thank you oh so much for your time and this wonderful opportunity using photovoice as a means of expressing our experiences and our thoughts about being in prison and since our release. It was a fun way to show what life means to us now and I truly hope that we have contributed in a helpful way. I am really excited to come along to the exhibition.

Kate: I was unsure about participating at first, but it's been good. I liked that you came to my home and that we talked one to one. I liked taking the pictures instead of having a long interview, you can just give a snapshot of what you want to say. It will be nice to see the photos that other people take 
too, but even you saying that other people have similar thoughts is really good isn't it? What I liked most about it is that people are taking an interest in me. You know, most people in society look at me and don't want to know me, but you are interested in me and what happened.

\section{Conclusion}

Along with participants benefiting individually from the project and being given a platform to inform the public about the realities of the prison and release experience, this has been an enriching experience for me. Much more than getting good data for my $\mathrm{PhD}$, I am deeply connected to the research and the days, weeks, and months that I have spent writing up my findings have been more pleasurable than onerous. The thrill of using a creative, arts-based method that has the potential to begin to sow the seeds of social change is invigorating. For social workers who are often alienated from their work and the people they work with, exploring the possibilities of arts-based methodologies is highly recommended.

Writing about the critical pedagogy of Freire, Lorde (1984) believed that "revolutionary change is never merely the oppressive situations which we seek to escape, but that piece of the oppressor which is planted deep within each of us" (p. 123). The use of photographs and accompanying narratives has provided opportunities for critical reflection as the public begin to see people who have been to prison holistically, rather than solely via the lens of criminality. Therefore, using photovoice has the potential to go beyond the walls of academia by generating research findings that the general public are interested in learning more about.

Having ex-prisoners speak for themselves using photography as a medium was empowering for the participants. Their images and narratives encouraged me to stretch my thinking, to reconsider my own assumptions and research questions far more broadly than if I had relied on an interview alone. Rather than being researched on, where personal deficits are named, diagnosed, and unpacked within the popular public discourse, participants became researchers and had control over the data they produced. As researchers, participants chose the topics they wanted to discuss and by doing so have generated new knowledge that is unlikely to have been discovered using positivist research methods.

Researchers' photographs and voices were seen and heard as they participated in an internationally recognised arts festival and their critical consciousness was raised as they engaged with the work of other researchers in the project. Collectively, they told their own history, communicating their experiences of prison and release to their loved ones, to workers in the social services, to social work students, and to the public. In doing so they have challenged the common stereotype of what constitutes an ex-prisoner and have contributed to the public discourse on some of the problematic functions of the criminal justice system.

\section{References}

Addams, J. (1912). Twenty years at Hull House. New York, NY: The Macmillan Company.

Adelaide Gaol Preservation Society. (2015). Retrieved from http://adelaidegaol.org.au/

Anleu, S. L. R. (1992). The professionalisation of social work? A case study of three organisational settings. Sociology, 26(1), 23-43.

Anwar McHenry, J. (2011). Rural empowerment through the arts: The role of the arts in civic and social participation in the Mid West region of Western Australia. Journal of Rural Studies, 27(3), 245-253.

Arditti, J., Lambert-Shute, J., \& Joest, K. (2003). Saturday morning at the jail: Implications of incarceration for families and children. Family Relations, 52(3), 195-204.

Baines, D. (2011). Doing anti-oppressive practice: Social justice social work. Black Point, Nova Scotia, Canada: Fernwood Publishing.

Beddoe, L. (2010). Surveillance or reflection: Professional supervision in 'the risk society'. British Journal of Social Work, 40(4), 1279-1296.

Beresford, P. (2011). Radical social work and service users: A crucial connection. In M. Lavalette (Ed.), Radical social work today: Social work at the crossroads (pp. 95-114). Bristol, United Kingdom: The Policy Press.

Bogre, M. (2011). Photography as activism. Oxford, United Kingdom: Focal. 
Brieland, D. (1990). The Hull-House tradition and the contemporary social worker: Was Jane Addams really a social worker? Social Work, 35(2), 134-138.

Brook, H. (2009). Dark tourism. Law Text Culture, 13(1), 260-272.

Brown, L., \& Strega, S. (2005). Transgressive possibilities. In L. Brown, \& S. Strega (Eds.), Research as resistance: Critical, Indigenous and anti-oppressive approaches (pp. 1-18). Toronto, Canada: Canadian Scholar's Press.

Castleden, H., \& Garvin, T. (2008). Modifying Photovoice for community-based participatory Indigenous research. Social Science \& Medicine, 66(6), 1393-1405.

Catalani, C., \& Minkler, M. (2010). Photovoice: A review of the literature in health and public health. Health Education and Behaviour, 37(3), 424-451.

Clemmer, D. (1940). The prison community. Boston, MA: Christopher House.

Cox, L., \& Nilsen, A. (2014). We make our own history: Marxism and social movements in the twilight of neoliberalism. London, United Kingdom: Pluto Press.

Craig, C. (2009). Exploring the self through photography: Activities for use in group work. London, United Kingdom: Jessica Kingsley Publishers.

Davis, A. (1984). Art on the frontline: Mandate for a people's culture. In A. Y. Davis (Ed.), Women, cuture and politics (pp. 198-218). New York, NY: Random House.

Davis, A. (2003). Are prisons obsolete? New York, NY: Seven Stories Press.

Decoster, V., \& Dickerson, J. (2014). The therapeutic use of photography in clinical social work: Evidence-based best practices. Social Work in Mental Health, 12(1), 1-19.

Dunbar, R. (1970). Female liberation as the basis for social revolution. In R. Morgan (Ed.), Sisterhood is powerful: An anthology of writings from the women's liberation movement (pp. 477-492). New York, NY: Random House.

Eltham, B. (2009). Is the carnival over? Meanjin, 68(4), 42-51.

England, H. (1986). Social work as art: Making sense for good practice. London, United Kingdom: Allen \& Unwin.

Faith, K. (2000). Reflections on inside/out organising. Social Justice, 27(3), 158

Ferguson, I. (2004). Neoliberalism, the third way and social work: The UK experience. Social Work and Society, 2(1), 1-9.

Ferguson, I. (2008). Reclaiming social work: Challenging neo-liberalism and promoting social justice. London, United Kingdom: Sage.

Ferguson, I., \& Lavalette, M. (2004). Beyond power discourse: Alienation and social work. British Journal of Social Work 34 (3), 297-312.

Ferguson, I., \& Lavalette, M. (2007). "Dreaming a great dream": Prospects for a new radical social work. Canadian Social Work Review, 24(1), 55-70.

Ferguson, I., \& Woodward, R. (2009). Radical social work in practice: Making a difference. Bristol, United Kingdom: The Policy Press.

Ferguson, I., Lavalette, M., \& Mooney, G. (2002). Rethinking welfare: A critical perspective. London, United Kingdom: Sage.

Fischer, E. (1963). The necessity of art: A Marxist approach. Middlesex, England: Penguin Books.
Foerstner, A. (1989). Hull House history through Wallace Kirkland's camera. Retrieved from http://articles.chicagotribune.com/1989-09-22/ entertainment/8901150389_1_dance-classes-charleshull-life-magazine

Fook, J. (1993). Radical casework: A theory of practice. New South Wales, Australia: Allen \& Unwin.

Freire, P. (1970). Pedagogy of the oppressed. New York, NY: Seabury Press.

Freire, P. (1998). Pedagogy of freedom: Ethics, democracy, and civic courage. Latham, MD: Rowman \& Littlefield.

Giroux, H. (2002). Neoliberalism, corporate culture, and the promise of higher education: The university as a democratic public sphere. Harvard Educational Review, 72(4), 425-463.

Giroux, H. (2010). Rethinking education as the practice of freedom: Paulo Freire and the promise of critical pedagogy. Retrieved from http://www.truth-out.org/ archive/item/87456:rethinking-education-as-the-practiceof-freedom-paulo-freire-and-the-promise-of-criticalpedagogy

Glasby, J., \& Beresford, P. (2006). Who knows best? Evidence-based practice and the service user contribution. Critical Social Policy, 26(1), 268-284

Gray, M., \& Webb, S. (2008). Social work as art revisited. International Journal of Social Welfare, 17(2), 182-193.

Green, D. (2009). Feeding wolves: Punitiveness and culture. European Journal of Criminology, 6(6), 517-536.

Halsey, M. (2007). Assembling recidivism: The promise and contingencies of post-release life. Journal of Criminal Law and Criminology, 97(4), 1209-1260.

Harvey, J. (1999). Civilised oppression. Washington, DC: Rowman \& Littlefield.

Harvey, J. (2010). Victims, resistance and civilised oppression. Journal of Social Philosophy, 41(1), 13-27.

Hegar, R. (2012). Paulo Freire: Neglected mentor for social work. Journal of Progressive Human Services, 23(2), 159-177.

Heiferman, M. (2012). Photography changes everything. New York, NY: Aperture Foundation Books.

Henman, P., \& Marston, G. (2008). The social division of welfare surveillance. Journal of Social Policy, 37(2), 187-205.

hooks, b. (1994). Teaching to transgress: Education as the practice of freedom. New York, NY: Routledge.

Ife, J. (2009). Human rights from below: Achieving rights through community development. Port Melbourne, Victoria: Cambridge University Press.

Jarldorn, M. (2016). What can Ruby do with a camera? Ex-prisoners use Photovoice to reverse the rules of surviellance. Qualitative Social Work, 15(2), 209-230.

Kohm, S. (2009). Naming, shaming and criminal justice: Mass-mediated humiliation as entertainment and punishment. Crime Media Culture, 5(2), 188-205.

Kuratani, D., \& Lai, E. (2011). Photovoice literature review. Retrieved from http://teamlab.usc.edu/Photovoice\%20 Literature\%20Review\%20\%28FINAL\%29.pdf

Lavalette, M. (2011). Radical social work today: Social work at the crossroads. Bristol, United Kingdom: The Policy Press. 
Lockett, T. (2011). Remembering Lewis Hine. The Humanist, $71(5), 18-25$

Lorde, A. (1984). Sister outsider: Essays and speeches. New York, NY: Crossing Press.

Marshall, H., Craun, S., \& Theriot, M. (2009). The big picture: How social work can effectively utilize photographs. Social Work, 54(4), 317-325.

Marx, K. (1972). Thesis on Feuerbach. In R. Tucker (Ed.), The Marx-Engels reader (pp. 107-109). New York NY: WW Norton \& Company.

Marx, K., \& Engels, F. (1972). The German ideology. In R. Tucker (Ed.), The Marx-Engels reader (pp. 110-164). New York, NY: WW Norton \& Company.

Marx, K., Engels, F., Baxandall, L., \& Morawski, S. (1973). Karl Marx and Frederick Engels on literature and art. New York, NY: International General.

Mendes, P. (2003). Australia's welfare wars: The players, the politics and the ideologies. Sydney, Australia: University of New South Wales Press.

Molloy, J. (2007). Photovoice as a tool for social justice workers. Journal of Progressive Human Services, 18(2), 39-55.

NSW Art Gallery. (2008). Half light: Portraits from Black Australia. In H. Perkins, \& J. Jones (Eds.). Sydney, Australia: Author.

Ollman, B. (1971). Alienation: Marx's conception of man in capitalist society. London, United Kingdom: Cambridge University Press.

Parr, J. (1998). Theoretical voices and women's own voices: The stories of mature women students. In R. Edwards, \& J. Ribbens (Eds.), Feminist dillemmas in qualitative research (pp. 87-101). London, United Kingdom: Sage.

Petersilia, J. (2003). When prisoners come home: Parole and prisoner reentry. New York, NY: Oxford University Press.

Prodger, M. (2012). Photography: Is it art? Retrieved from http://www.theguardian.com/artanddesign/2012/oct/19/ photography-is-it-art

Quick, S. (2015). Beyond bars. The Big Issue, 20-21.

Reinharz, S. (1992). Feminist methods in social research. New York, NY: Oxford University Press.

Reitz, C. (2000). Art, alienation and the humanities: A critical engagement with Herbert Marcuse. New York, NY: SUNY Press.

Ruby, J., Gross, L., \& Katz, J. (1988). Image ethics: The moral rights of subjects in photographs, film and television. New York, NY: Oxford University Press.

Russell, A., \& Diaz, N. (2013). Photography in social work research: Using visual image to humanize findings. Qualitative Social Work, 12(4), 433-453.

Sontag, S. (1977). On photography. London, United Kingdom: Penguin.

Sontag, S. (2003). Regarding the pain of others. London, United Kingdom: Hamish Hamilton.

Spence, J., \& Solomon, J. (1995). What can a woman do with a camera? London, United Kingdom: Scarlett Press.

Steinberg, D. (2006). The art, science, heart and ethics of social group work: Lessons from a great teacher. Social Work With Groups, 29(2), 33-45.

Stirling, C., Warren, R., \& Paton, C. (2014). Social work and the arts: Images at the intersection. Qualitative Social Work, 13(2), 187-202.
Terry, C. (2003). The fellas: Overcoming prison and addiction. Belmont, CA: Wadsworth/Thomson Learning.

The History Place. (n.d.). Child labour in America, 1908-1912: Photographs of Lewis Hine. Retrieved from http://www. historyplace.com/unitedstates/childlabor/about.htm

Tranter, B., \& Donoghue, J. (2003). Convict ancestry: A neglected aspect of Australian identity. Nations and Nationalism, 9(4), 555-577.

Wallace, J., \& Pease, B. (2011). Neoliberalism and Australian social work: Accommodation or resistance? Journal of Social Work, 11(2), 132-142.

Wang, C. (1999). Photovoice: A participatory action research strategy applied to women's health. Journal of Women's Health, 8(2), 185-192.

Wang, C., \& Burris, M. (1997). Photovoice: Concept, methodology, and use for participatory needs assessment. Health, Education \& Behaviour, 24(3), 369-387.

Webb, S. (2001). Some considerations on the validity of evidence-based practice in social work. British Journal of Social Work, 31(1), 57-79.

Williams, M. (2015). Stain or badge of honour? Convict heritage inspires mixed feelings. Retrieved from https://theconversation.com/stain-or-badge-of-honourconvict-heritage-inspires-mixed-feelings-41097

Wilson, J. Z. (2008). Prison: Cultural memory and dark tourism. New York, NY: Peter Lang Publishing. 